\title{
Knowledge of primary health care professionals on health policies for the riverside population
}

\author{
Conhecimento de profissionais da atenção primária em saúde sobre política de saúde para populações ribeirinhas
}

Conocimiento de profesionales de atención primaria de salud sobre política de salud para poblaciones de ribereñas

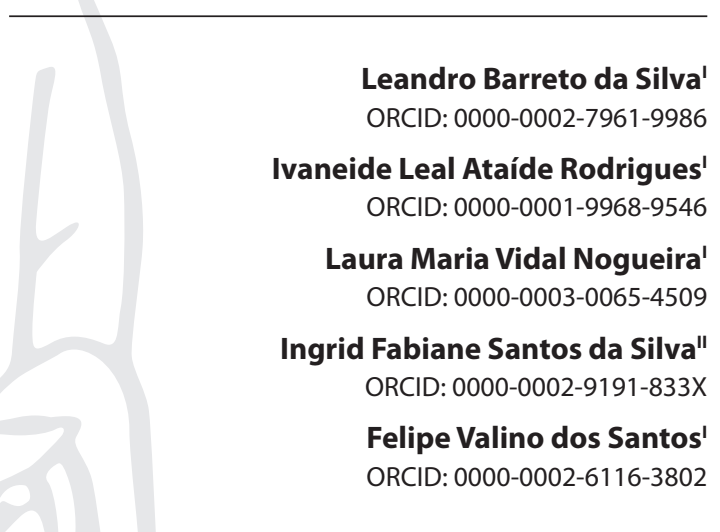

'Universidade do Estado do Pará. Belém, Pará, Brazil. "Universidade Federal do Rio de Janeiro. Rio de Janeiro,

Rio de Janeiro, Brazil.

How to cite this article: Silva LB, Rodrigues ILA, Nogueira LMV, Silva IFS, Santos FV. Knowledge of primary health care professionals on health policies for the riverside population.

Rev Bras Enferm. 2020;73(5):e20190080 doi: http://dx.doi.org/10.1590/0034-7167-2019-0080

Corresponding author: Ingrid Fabiane Santos da Silva E-mail: ingridenfermeir@gmail.com

EDITOR IN CHIEF: Antonio José de Almeida Filho ASSOCIATE EDITOR: Hugo Fernandes

Submission: 03-20-2019

Approval: 09-15-2019

\section{ABSTRACT}

Objectives: to analyze the knowledge of health professionals on the health policies for the riverside population; identify how health practices with this group are developed; and discuss facilitators and barriers for the implementation of these policies. Methods: qualitative and descriptive study with 24 professionals from the Riverside Family Health Strategy Teams in the city of Belém-Pará. Data were collected in individual interviews and analyzed by Content Analysis. Results: although professionals demonstrate knowledge about public health policies, there is a need to expand and strengthen knowledge about health policies for the riverside population. The activities directed to the communities took place in the Unit itself, and some did not occur due to insufficient material and human resources. Final Considerations: the greatest barrier for the organization of health care is the lack of material and human resources, and the most prominent facilitator was the union and cohesion of the health team.

Descriptors: Health Policy; Vulnerable Populations; Primary Health Care; Delivery of Health Care; Family Health Strategy.

\section{RESUMO}

Objetivos: analisar conhecimentos dos profissionais de saúde sobre a política de saúde para a população ribeirinha; analisar o desenvolvimento das práticas de saúde direcionadas a esse grupo e discutir facilidades e dificuldades de implementar essa política. Métodos: estudo qualitativo, descritivo, com 24 profissionais das Equipes de Estratégia Saúde da Família Ribeirinha no município de Belém-Pará. Os dados foram produzidos em entrevista individual e analisados por Análise de Conteúdo. Resultados: embora os profissionais conheçam algo da política pública de saúde, há necessidade de ampliar e fortalecer conhecimentos sobre a política de saúde para população ribeirinha. As atividades direcionadas às comunidades ocorriam na própria Unidade, sendo que algumas não eram desenvolvidas por insuficiência de recursos materiais e humanos. Considerações Finais: a maior dificuldade para a organização da assistência à saúde é a carência de recursos materiais e humanos, e a maior facilidade é a união e coesão na equipe de saúde.

Descritores: Política de Saúde; Populações Vulneráveis; Atenção Primária em Saúde; Assistência à Saúde; Estratégia Saúde da Família.

\section{RESUMEN}

Objetivos: analizar el conocimiento de los profesionales de la salud sobre la política de salud para la población ribereña; analizar el desarrollo de prácticas de salud dirigidas a este grupo en la implementación de esta política. Métodos: estudio cualitativo y descriptivo con 24 profesionales de los Equipos de Estrategia en Salud de la Familia Ribereña en la ciudad de Belém-Pará. Los datos fueron producidos en entrevistas individuales y analizados por Análisis de Contenido. Resultados: aunque los profesionales sepan algo sobre políticas de salud pública, existe la necesidad de expandir y fortalecer el conocimiento sobre políticas de salud para la población ribereña. Las actividades dirigidas a las comunidades tuvieron lugar en la propia Unidad. Consideraciones Finales: la mayor dificultad para la organización de la atención de la salud es la falta de recursos materiales y humanos, y la más fácil es la unión y la cohesión en el equipo de salud.

Descriptores: Política de Salud; Poblaciones Vulnerables; Atención Primaria de Salud; Cuidado de la Salud; Estrategia de Salud Familiar. 


\section{INTRODUCTION}

Primary health care should be developed through democratic and participatory care and management practices, in the spirit of teamwork. The actions are directed to the population of defined territories, in which the teams assume the responsibility for health care, considering the existing dynamics and the uniqueness and socio-cultural aspects of the subjects ${ }^{(1-2)}$.

According to the National Policy of Primary Care (PNAB), the Basic Health Unit (BHU) is of paramount importance, as it must ensure accessibility and receive the population who comes to health services. It is also within its competence to coordinate comprehensive care by providing decisive care and equity of treatment according to the needs of each user, serving as a gateway to the Health Care Networks (RAS), and referencing the users of the Unified Health System (SUS) according to their needs ${ }^{(1)}$.

In this context, the Family Health Strategy (FHS) is the priority plan for the expansion and consolidation of the PNAB. This strategy enables the follow-up of most of the health/disease process throughout the life cycle, providing a comprehensive care. Thus, it is necessary to develop bonds and foster responsibility among team members, between them and users, in order to ensure the continuity of care in a process centered on the patient, enabling clinical and permanent monitoring of health interventions ${ }^{(1)}$.

Although Brazilian society has changed in recent years, originating large urban conglomerates, there are still remnant traditional populations that live outside them and preserve their own means of spatial and sociocultural reproduction. The guarantee of health care for these vulnerable populations is manifested through the National Policy of Integral Health of Rural, Forest and Water Populations (PNSIPCFA) which is based on the principle of equity. It seeks to recognize differences in living conditions, health and people's needs, understanding that the right to health access must recognize social differences, addressing diversity and ensuring access of these population groups to $S U S^{(3)}$.

The inclusion of these population in the PNAB occurs through the teams of the Riverside Family Health Strategy (RFHS), which are different from the FHS teams for the urban population, as the RFHS teams need different organization to build a work process that guarantees riverside communities full access to health ${ }^{(4)}$.

The place of work of RFHS professionals is these communities, which are surrounded by rivers and river arms and are very difficult to access, as in most cases the only means of access is through river transportation. This geographical feature leads to difficulties in transportation and hinders access to health services, despite of these communities being geographically close to large urban centers, and also causes difficulties for professionals. In addition, professionals must know the guiding principles of Primary Care and understand local culture to gain the trust of the community, forming bonds and guaranteeing the continuity of care ${ }^{(5)}$.

This is the reality of health professionals working in the RFHS, where the health care management requires a great capacity of adaptation. It is important to ensure full access to health for the riverside population, with a service that is not static, but adjusted according to the needs reported by its users, who are often literally on the 'margins' of Brazilian public health ${ }^{(5)}$.

\section{OBJECTIVES}

To analyze the knowledge of health professionals on the health policies for the riverside population; identify how health practices with this group are developed; and discuss factors that help or hinder the implementation of these policies.

\section{METHODS}

\section{Ethical aspects}

The research complied with CNS Resolution 466/2012 ${ }^{(6)}$ and was approved by the Research Ethics Committee of the Undergraduate Nursing Course of the State University of Pará. The participants received an Informed Consent Term to express their acceptance to participate in writing. Anonymity is guaranteed by the use of an alphanumeric code, with the letter $\mathrm{P}$, for professional, followed by the interview order number.

\section{Type of study and setting}

Descriptive qualitative study, based on the Consolidated Criteria for Reporting Qualitative Studies - COREQ $^{(7)}$, conducted from February to May 2018 in four Family Health Units (FHU), with teams from the Riverside Family Health Strategy (RFHS) in the city of Belém, state of Pará. According to the Ministry of Health, there are 95 RFHSs in five states in the Northern region of the country, of which 38 are in Pará and 07 are in Belém ${ }^{(8)}$. The institutions selected for the study were RFHS: Águas Lindas Ilha de Cotijuba; Furo das Marinhas and Sucurijuquara. These represent $57 \%$ of the RFHSs in Belém and are distributed in the various Administrative Districts and managed by the Belem Municipal Health Office (SESMA).

\section{Data sources}

Twenty-four of the 31 professionals who worked in the selected RFHS participated in the study, corresponding to $77.4 \%$. All professionals who had worked at RFHS teams for at least six months and were exercising their professional activities during the data collection period were included. Seven professionals were excluded due to the unavailability of dates for the interviews.

\section{Data collection and organization}

Data were collected through individual interviews with a semi-structured form applied by the researcher, which contained questions about knowledge on public health policies for the riverside population, about how health practices with this group are developed and about the difficulties and challenges for the effective implementation of these policies.

Participants were approached in the $\mathrm{BHU}$. The first contact was with the management of the services, which gathered the professionals to present the project, clarify doubts and invite to participate. Interviews were scheduled according to the availability of the professionals and were held in a room in the Unit. The interviews were recorded with prior authorization and later transcribed, ensuring the reliability of the statements. 


\section{Analysis of data}

The content analysis technique ${ }^{(9)}$ was used and the corpus composed of the interviews was organized according to the most recurrent themes mentioned by the participants. Subsequently, a global analysis of the responses was conducted, looking for common themes, which led to the identification of 12 themes: concept of public policy, concept of specific policy, physical structure of the unit, lack of human, material and financial resources, support from management, planning of activities, access of the population and the professionals, teamwork, working conditions and the importance of training.

The themes were organized into two thematic categories, meeting the objectives of the study: "knowledge and practices of professionals regarding health policies for the riverside population" and "facilitators or barriers for the assistance to the riverside population". Data were discussed in the light of the most recent scientific evidence on the subject, in addition to current legislation and official documents from the Ministry of Health.

\section{RESULTS}

Among the participants, 21 were female (87.5\%). The age ranged from 23 to 72 years and age group of 30 to 45 years prevailed, with 11 professionals (45.8\%). Regarding the professional categories, there were $13(54.1 \%)$ community health agents, four (16.6\%) nurses, two (8.3\%) doctors and five (21\%) nursing technicians. Formal employment bonds predominated, with 22 participants $(91.6 \%)$, and the time of work in the team ranged from 7 months to 15 years. Nine participants (37.5\%) reported working in the teams for five to six years. Regarding graduate studies, three (12.5\%) professionals had completed specialization.

\section{Knowledge and practices of professionals regarding health policies for the riverside population}

This category addresses the knowledge of health professionals about the public health policies and the care actions for riverside communities.

Sixteen professionals (66.6\%) understand the concept of public health policies as the set of actions, measures, programs, projects and plans developed by the Municipal, State and Federal governments, aimed at better serving the general population, considering general aspects of health and also their specific needs. Here are some statements on this issue:

[...] Public policies are policies that should properly serve the general population, [...] in the general context of the population and in each group, with its peculiarities, like the hypertensives, diabetics. (P1)

[...] These are policies made for the population, including consultations and medical services, nursing and our work in the FHS; we work in prevention services. (P11)

[...] These are actions that are established by the government, mainly to comply with the Unified Health System, and developed by us. The government has good programs for diabetes, hypertension, prenatal care, leprosy, tuberculosis, they are very good programs
[...], we, in the FHS, work more on health prevention and, with this prevention, we have been able to cover at least $80 \%$ of the population. (P24)

The participants demonstrated knowledge about the public health policies in general. However, when seeking specific knowledge about health policies for the riverside communities, it was found that 22 of the professionals (91.6\%) have little knowledge, according to the following reports:

[...] l, particularly, do not know a specific public policy on health of the riverside population. I know they have some benefits, they get different consultations, but I don't know about anything health related. [...]. I have doubts... (P12)

[...] I don't know all of them, I know some parts, but I have many doubts, because not all of them happen and not all are applied here in the unit. (P20)

[...] the policy for the riverside populations is a totality, I don't see the riverside population as a single and isolated issue, it is within the context of the whole unit or work; there is not something aimed just at this issue, at least here we don't have it. I don't know, I have doubts about these policies. (P15)

Regarding professional practices directed to health care for riverside populations, $100 \%$ of professionals reported that actions such as lectures, nursing and medical consultations and others are planned and developed within the Health Units, meeting the demands that arrive at the Health Unit, despite of the difficulties faced by these population to access health services.

[...] We do all the activities here at the Unit when they come, and when we go to the community, but it is from time to time, usually in vaccination campaigns. (P8)

[...] Medical consultations, nursing consultations, pap smear, neonatal heel prick, vaccination, [...] including the riverside population, when they come to us. (P9)

[...] Lectures, actions, activities with health education topics, such as sex education, breast cancer, pregnancy and child care, among others. We always try to have these activities with the riverside population here in the Unit. We are always scheduling, yet there is always the factor of the tides. We always schedule with a week notice, so that the tide does not hinder their coming. Sometimes they can come to the Unit and we do all the activities with them. (P22)

As for the actions that should be developed within the community, 21 professionals (87.5\%) reported that they do not follow previous planning, and that most of the actions are carried out in the community during vaccination campaigns. During these campaigns, the professionals take advantage of the available resources and perform home visits, medical and nursing consultations, educational activities, among others.

[...] Medical care, nursing care, vaccination, conversation circles, among other programs, as requested by the coordination of each program of the Ministry of Health, are developed here in the FHS. (P19) 
[...] We address the riverside population here like this... Access occurs when we get a budget for vaccination. When this vaccination money comes, in the form of gasoline, we give it to the boatman, and he takes us to the community, [...] we do the vaccination campaign with the riverside population, along with promotion and prevention actions, and on that day we have to do everything we can. Wherever we can get, we do this. (P16)

[...] We perform all Primary Care activities, [...] especially in Family Health, we work with prevention, with all the programs, we provide assistance, we teach, we care and we go to the riverside community. But we haven't gone there a lot, because material resources are lacking. Primary care... it has been about six months since we've last been to the riverside community, due to lack of resources. (P22)

\section{Facilitators and barriers for the assistance to the riverside population}

Facilitators and barriers for the health work process and for the health care of the riverside population are described here, as mentioned by professionals.

Regarding the facilitators, 22 professionals ( $80 \%$ ) mentioned that union and teamwork are factors that help organizing their work process. Their statements highlight the importance of joint planning to organize activities that can meet the real health needs of the riverside population.

[...] Availability of the CHAs to participate, as they do not refuse to perform activities. Whenever we need something, they are willing to do it [...]. The interaction, of course, is very good, and I always say that without their participation, it does not happen. (P1)

[...] The team is very good, so we work with this support. We can solve the issues that arise and, sometimes, we do the external activities of displacement with our own resources. So, we try to organize ourselves and make the service happen. (P11)

[...] Mainly the team. We have a very good and very cohesive team, and together, with everybody thinking, we organize and we have a good response. (P22)

Regarding the barriers to organize the assistance, 21 professionals (87.5\%) report that the working conditions to provide assistance to the riverside population do not favor the work process and, consequently, make health provision insufficient to meet demands. The lack of human and material resources, as well as the lack of adequate physical structure, were reported as the greatest difficulties to carry out health activities with the riverside communities:

[...] The difficulty is that the team is not always complete, with all the health professionals, as it is now, that we are without a doctor. (P2)

[...] Mostly material, because we are a family health service without dressings, without a pharmacy, without vaccination, without a boat to go to the riverside population and this is all basic in Primary Care and we do not have it here [...] If we do not have the vaccination campaign, we will not go to the riverside communities, because that is when we have the resources to go there, and then we take advantage and do everything possible with these populations. (P22)

[...] / think our Unit doesn't have the structure [...] everything is very small, and it has already been restructured. To put something here, we have to remove something else [...], we even have wheelchairs and a device to sterilize material that is not here, because we have no space to install. So, our physical space leaves a lot to be desired. (P15)

\section{DISCUSSION}

The understanding expressed by professionals is consistent with the general context of public health policies and with the care models proposed by SUS, as these are understood as a set of programs that aim to include all segments of the population, guaranteeing participation and accessibility to health services, as part of a full exercise of citizenship ${ }^{(10)}$.

Knowledge about the legislation on the organization of health care for the riverside populations is crucial to know the available resources and the duties of the professionals in this assistance. However, it was found that most professionals were unaware of the legislation that underpins the work and assistance to riverside communities, such as Ordinance No. 837/2014, which redefines the organization of the RFHS and Fluvial Family Health Teams (FFHS) of the cities in Brazil's Legal Amazon and discusses the organization, management and financing of Primary Care services for the riverside population ${ }^{(11)}$.

It is also important to know the National Policy of Comprehensive Health for Rural, Forest and Riverside Populations (PNSIPCFA), created in 2011 to address the needs of these populations, promoting access to health actions and services, reducing risks and health problems related to work processes and agricultural technologies, and improving health indicators. This policy was constructed with broad debate with the most varied representations of traditional communities ${ }^{(12)}$. It seeks to recognize the needs of specific groups, in this case, the riverside population, acting to reduce the impact of the social determinants of health to which they are subjected.

Regarding the actions and health services developed by professionals, it was found that, although they strive to plan external actions, most often they can only act within the scope of the FHS itself, meeting the demands of the part of the population who can travel to the service, as professionals have few resources to travel to the community.

It is worth noting that, even though the RFHS also has attributions to be developed at the FHU - such as updating the family register; providing health care and actions; user reception; active search and notification of diseases, among others - the main characteristic of its strategic action is to act directly with the community, providing actions and services to meet the unique needs of each population ${ }^{(13)}$.

Similarly, to what occurs in the RFHSs included in this study, other Brazilian cities also face difficulties that are often related to institutional failure in resource management for financing assistance and services. Lack of incentive, represented by the lack of financial resources and mismanagement of public funds, hinder the continuity of actions and the services and assistance necessary to meet the needs and maintain health programs for the population ${ }^{(14)}$. 
Among the factors that help professionals providing assistance to riverside communities, teamwork stands out. This is described by the participants and by scholars who study collective health ${ }^{(15-16)}$ as a foundation that ensures the proper functioning of the work process in the FHS, through the construction of an interdisciplinary practice with knowledge and actions with collective purposes that extend beyond the specific technical knowledge of each professional. Therefore, the meetings of the multi-professional team of the FHS are important to understand and organize interdisciplinary health actions and are an essential space for exchange of knowledge and integration, where comprehensive care can be promoted.

On the other hand, these professionals face many difficulties to perform their activities. The lack of adequate conditions to provide health care for the riverside population is the main difficulty in the daily routine of health services. The lack of infrastructure in the Health Units and the lack of transportation to perform home visits are factors that hinder the provision of health services to the community ${ }^{(4)}$.

A work environment that provides the necessary conditions to the professionals, and investments in Primary Care and in the structure of health services, with physical spaces that are appropriate to professionals and users and that can avoid the stress of performing activities in small environments, are necessary resources. In addition, material resources and supplies must be provided in appropriate quality and quantity ${ }^{(17)}$

Besides these barriers, there is the permanent lack of human resources, always mentioned by professionals for the provision of services to the community. This factor leads to incomplete teams that create a great difficulty for the concrete implementation of SUS principles, such as universality, integrality and equity in health care for riverside populations in the national territory ${ }^{(18)}$.

\section{Limitations of the study}

The fact that the registered RFHS are dispersed throughout the territory of the State of Pará is understood as limitation for the development of this study, as it hinders the researchers' access, from an operational point of view. Regarding the analysis of the results, there were some limitations due to the lack of scientific studies related to the object of study, which made it difficult to compare the results with other studies.

\section{Contributions to the area of nursing}

The results presented here are considered expressive and it is hoped that they can support the performance of the health team, especially in the nursing area, and that they offer evidence for further studies and research, as well as for the organization of assistance to riverside communities considering their sociocultural reality, which is still a major challenge for collective health.

\section{FINAL CONSIDERATIONS}

The results of this study demonstrated that the conditions under which the teams organize their work process are not ideal for the provision of comprehensive and equitable health care to the riverside communities, as recommended by SUS.

It was found that, even though these professionals know the public policies that organize Primary Health Care, there is still a need to expand and strengthen this knowledge when it comes to the specific policies for the riverside population, as these should be the basis to organize assistance activities and to know the resources available for its execution.

Most of the activities directed to the riverside communities occurred at the RFHS, and only met the spontaneous demand. It is worth noting that the teams are willing to go to the communities, however, the lack of resources, such as boats and other supplies are barriers for these professionals to organize themselves to provide assistance and continuous follow up and to establish bonds with the communities.

A positive point to highlight is the multi-professional work and the strong union and cohesion between team members, which supports the organization and planning of assistance activities for the riverside communities, even with the lack of human and material resources. This interaction allows sharing the organization of the work process with the most varied professional categories, creating a bond between them and improving the development of activities on behalf of users.

Thus, there were barriers to overcome and facilitators that help managers and professionals to be aware of the need for a joint effort to press for resources to maintain the programs and enable better working conditions.

\section{REFERENCES}

1. Ministério da Saúde (BR). Secretaria de Atenção à Saúde. Departamento de Atenção Básica. Política Nacional de Atenção Básica. Brasília: Ministério da Saúde; [Internet] 2012[cited 2019 Jan 16]. Available from: http://bvsms.saude.gov.br/bvs/publicacoes/politica_nacional_atencao_ basica.pdf

2. Carvalho MN, Gil CRR, Costa EMOD, Sakai MH, Leite SN. Needs and dynamics of the Primary Healthcare workforce in Brazil. Ciênc Saúde Colet. 2018;23(1):95-302. doi: 10.1590/1413-81232018231.08702015

3. Ministério da Saúde (BR). Secretaria de Gestão Estratégica e Participativa, Departamento de Apoio à Gestão Participativa. Política Nacional de Atenção de Saúde Integral das Populações do Campo e da Floresta[Internet]. Brasília: Ministério da Saúde; 2013 [cited 2019 Jan 16]. Available from: http://bvsms.saude.gov.br/bvs/publicacoes/politica_nacional_saude_populacoes_campo.pdf

4. Ministério da Saúde (BR). Portaria n. 2.488, de 21 de outubro de 2011. Aprova a Política Nacional de Atenção Básica, estabelecendo a revisão de diretrizes e normas para a organização da Atenção Básica, para a Estratégia Saúde da Família (ESF) e o Programa de Agentes Comunitários de Saúde (PACS) [Internet]. Diário Oficial da União, 21 out 2011 [cited 2019 Jan 16]. Available from: http://bvsms.saude.gov.br/bvs/saudelegis/ gm/2011/prt 2488_21_1_2011.html 
5. Brasil GB, dos Santos DKA, Nogueira LMV, Rodrigues ILA. Modo de vida ribeirinho e a longitudinalidade do cuidado na atenção primária em saúde. Saúde (Santa Maria). 2016;42(1):31-8 doi: 10.5902/2236583417186

6. Ministério da Saúde (BR). Conselho Nacional de Saúde. Diretrizes e normas regulamentadoras de pesquisa envolvendo seres humanos. Resolução n.466, de 12 de dezembro de 2012. Brasília; [Internet] 2012[cited 2019 Jan 16]. Available from: http://conselho.saude.gov.br/ resolucoes/2012/Reso466.pdf

7. Tong A, Sainsbury P, Craig J. Consolidated criteria for reporting qualitative research (COREQ): a 32-item checklist for interviews and focus groups. Int J Qual Health Care. 2007;19(6):349-57. doi:10.1093/intqhc/mzm042

8. Jornal do Site Odonto [Internet]. Atendimento de saúde a famílias ribeirinhas no Norte ganha reforço de R\$ 2,2 mi. Jornal do Site Odonto. Arquivo Útimas Notícias. 2016[cited 2019 Jan 16]. Available from: http://www.jornaldosite.com.br/materias/ultimasnoticias/anteriores/ abril2016/ultimasnoticias25042016-4.htm

9. Bardin L. Análise de Conteúdo. São Paulo; Edição 70; 2011.

10. Duarte MPST. Visão dos estudantes do IFAL acerca da educação, inclusão e políticas públicas: uma realidade de inclusão dos alunos do ensino médio no Instituto Federal de Educação, Ciência e Tecnologia de Alagoas - IFAL. Psicol Saberes. 2015; 4(5): 23-41. doi: 10.3333/ps.v4i5.728

11. Ministério da Saúde (BR). Portaria n837, de 9 de maio de 2014. Redefine o arranjo organizacional das Equipes de Saúde da Família Ribeirinha (ESFR) e das Equipes de Saúde da Família Fluviais (ESFF) dos Municípios da Amazônia Legal e do Pantanal Sul-Mato-Grossense[Internet]. Diário Oficial da União 9 mai 2014[cited 2019 Jan 16]. Available from: http://bvsms.saude.gov.br/bvs/saudelegis/gm/2014/ptr 0837_09_05_2014.html

12. Ministério da Saúde (BR). Secretaria de Gestão Estratégica e Participativa, Departamento de Apoio à Gestão Participativa Saúde e Ambiente para as Populações do Campo, da Floresta e das Águas[Internet]. Brasília: Ministério da Saúde; 2015[cited 2019 Jan 16]. Available from: http:// bvsms.saude.gov.br/bvs/publicacoes/saude_ambiente_populacoes_campo_floresta_aguas.pdf

13. Forte ECN, Pires DEP, Scherer MDA, Soratto J. Does the nurses' work change when the Primary Health Care change? Tempus (Brasília). 2018;11(2):53-68. doi: 10.18569/tempus.v11i2.2338

14. Lima SAV, Silva MRF, Carvalho EMF, Cesse EAP, Brito ESV, Braga JPR. Factors that influence access to primary care in the perspective of professionals and users of a health services network in Recife-PE, Brazil. Physis (Rio J.). 2015;25(2):635-56. doi:10.1590/S0103-73312015000200016

15. Chiconatto $P$, Schmitt V, Bernardi L, Menon MU, Novello D. Percepção Sobre a existência de trabalho interdisciplinar em estratégias saúde da família da cidade-sede da 5a Regional de Saúde do Paraná. Revista da Universidade Vale do Rio Verde. 2018;16(1):1-14. doi:10.5892/ruvrd.v16i1.3768

16. Tambasco LP, Silva HS, Pinheiro KMK, Gutierrez BAO. Satisfaction in the work of the multidisciplinary team which operates in primary health care. Saúde debate. 2017;41(n.esp):140-151. doi: 10.1590/0103-11042017s212

17. Bardaquim VA, Dias EG, Robazzi MLCC. O processo de trabalho do (a) enfermeiro (a) na constituição da equipe de uma estratégia de saúde da família: um relato de experiência. Saúde Redes. 2017;3(3):293-300. doi: 10.18310/2446-4813.2017v3n3p293-300

18. Franco EC, Santo CE, Arakawa AM, Xavier A, França ML, Oliveira AN, et al. Riverside population: experience report. Rev CEFAC. 2015;17(5):152130. doi:10.1590/1982-0216201517518714 